\title{
A Review on Phytomedicine and Their Mechanism of Action on PCOS
}

\section{Sudhakar Pachiappan, Kothai Ramalingam, Arul Balasubramanian}

Section: Healthcare

Sci. Journal Impact

Factor: $6.1(2018)$

ICV: 90.90 (2018)

(c) (i) (3)

Copyright@IJCRR

Department of Pharmacology, Vinayaka Mission's College of Pharmacy, Vinayaka Mission's Research Foundation (Deemed to be University), Salem -8, Tamil Nadu, India

\section{ABSTRACT}

Introduction: Polycystic ovary syndrome (PCOS) is characterized by gynaecological endocrine and metabolic abnormality of women at reproductive ages. It is established that hyperandrogenism, insulin resistance, menstrual abnormalities, and chronic absence of ovulation of polycystic ovary are commonly associated with symptoms. It might indicate the multidisciplinary approach for the therapeutic management of PCOS. Conventional medical management concentrated single symptom, is often associated with the side effect, maybe contraindicated and ineffective in some conditions. So far women with PCOS have expressed a desire for alternative medicine. Ayurvedic medicine has been emerging as one of the commonly practised medicines for different health problems, including PCOS.

Objective: In this review, an attempt has been made to study the use and mode of action of potential Ayurvedic drugs for the treatment of PCOS.

Method: This review is mainly based on the scientific literature search. The first search on plant possesses multiple effects against PCOS reproductive and metabolic complications. Selected plants from the first search were used as a keyword for the second search.

Result: They include Cinnamomum zeylanium, Gymnema sylvestre, Mentha spicata, Pergularia daemia, Saraka indica, Saw palmetto, Tribulus terrestis, and Withania somnifera. The second search sought the reproductive endocrinal and metabolic demonstrated mechanism of the selected plants.

Conclusion: This review supports the alternative Ayurvedic medication as a standard effective and safe drug in the management of PCOS.

Key Words: Medicinal Plants, PCOS, Anti-androgenic, Insulin resistance, Menstrual irregularity, Mechanism of action

\section{INTRODUCTION}

Polycystic ovary syndrome (PCOS) is a complex endocrinal reproductive disorder in a coalition with metabolic abnormalities of women at reproductive stages. PCOS characterized by hypergonadotropism, hirsutism, irregular and painful menstrual cycles, amenorrhea, multiple cysts in ovaries, anovulation which is commonly associated with infertility. ${ }^{1}$ It is also characterized by multiple metabolic abnormalities, such as insulin resistance, hyperinsulinemia, high incidence of impaired glucose tolerance, obesity, inflammation, endothelial dysfunction, hypertension, and dyslipidemia resulting in an increased risk for diabetes and cardiovascular disease. ${ }^{2-4}$ Besides, compromised quality of life, anxiety, and depression is also observed in PCOS. ${ }^{5}$
Existing treatment approaches to PCOS are limited due to the prevalence of contraindication in PCOS women, treatment failure in some circumstances, and may cause some severe side effects. This challenging drawback of current therapy for PCOS in women making an interest in an alternative treatment called Ayurvedic treatment. It is a natural way to treat the diseased condition without causing any serious side effects. ${ }^{6-7}$ The usage and acceptability of complementary medicine by women has increased from $26 \%$ to $91 \%$ during the past ten years. ${ }^{8}$. Recent day global health debates getting significant attention towards traditional herbal medicines. However herbal medicines are fighting to be recognized as a standard medication with its own identity. It is become necessary to show that herbal therapy can match

\section{Corresponding Author:}

Dr. R. Kothai, M.Pharm., Ph.D., Department of Pharmacology, Vinayaka Mission's College of Pharmacy, Vinayaka Mission's Research Foundation (Deemed to be University), Salem-636008, Tamil Nadu, India; Phone: +91 9600966775; Email: kothaiarul@yahoo.co.in

ISSN: 2231-2196 (Print)

Received: 10.08 .2020
ISSN: 0975-5241 (Online)

Revised: 25.09 .2020
Accepted: 22.10 .2020
Published: 07.12 .2020 
other fields of medicine in the thoroughness of its pharmacology and standardization of its practical use. Hence the focus of this study was to investigate plants possess multiple pharmacological actions in relevance to PCOS complication and to review its mechanism of action in PCOS condition, to improve its therapeutic wide acceptability and exploration of some standard herbal/ polyherbal formulations in PCOS.

\section{MATERIALSD AND METHODS}

In this study, we carried out two searches of the scientific literature. The first search on plants reported with multiple reproductive endocrine effects in hyperandrogenism, menstrual irregularity, and multiple cysts in ovaries, and also on metabolic effects in insulin resistance and hyperlipidemia. In the second search sought the reproductive endocrinal and metabolic demonstrated mechanism of the effect of the selected plants.

From the first search, we selected eight plants with multiple pharmacological effects on PCOS. These were Cinnamomum zeylanium, Gymnema Sylvestre, Mentha spicata, Pergularia daemia, Saraka indica, Saw palmetto, Tribulus terrestis, and Withania somnifera. The selected plants with a demonstrated mechanism of action were entered as key terms in the second search.

We searched from the following electronic databases: MEDLINE, EMBASE, PubMed, Google Scholar, Research gate and Science direct from the date of database inception to October 2019. Also, a search was made manually on the references of reviewed articles. First search key terms are title or abstract included 'herbal medicine' or 'herbal extract' or' phytotherapy' or 'phytomedicine' and title or abstract contains 'androgen' or 'Estrogen' or 'follicle stimulating hormone' or 'luteinizing hormone' or 'prolactin' or 'insulin' or 'glucose' or 'polycystic 'ovary' or 'PCOS'. Search terms for the second search included the following keywords in the title or abstract, contains; 'Mechanism' 'menstrual irregularity' or 'oligomenorrhoea' or 'amenorrhoea' or 'hyperandrogenism' or 'hirsutism' or 'acne', or 'polycystic ovary syndrome' or 'PCOS' and 'Cinnamomum zeylanium' or 'Gymnema sylvestre' or 'Mentha spicata' or 'Pergularia daemia' or 'Saraka indica' or 'Saw palmetto' or 'Tribulus Terrestris' or 'Withania somnifera'.

\section{Medicinal plants and their mechanism of ac- tion on PCOS}

\section{A. Cinnamomum zeylanicum}

Cinnamomum zeylanicum found to be an effective therapeutic agent for PCOS because it has been shown to improve both the reproductive and metabolic aspects of PCOS. Antiandrogenic mechanism: Oral administrations of cinnamon extract $(10 \mathrm{mg} / 100 \mathrm{~g})$ downregulate testosterone in dehydroepiandrosterone induced PCOS mice. Insulin resistance in PCOS women with compensatory hyperinsulinemia induces overproduction of androgen in the ovary. This action is mediated through the activation of insulin-like growth factor-1 (IGF-1) receptors on theca and stroma cells. In granulosa cells, IGF-1 stimulates estrogen production and regulates aromatase concentration. IGF-1 also acts synergistically with Luteinizing hormone ( $\mathrm{LH})$ to stimulate androgen production on theca cells. Increased serum level of insulin and IGF-1amplifies the effect of LH on granulosa cell leads to anovulation and affect follicular maturation. Hence the proposed anti- androgenic mechanism of cinnamon is mediated by the downregulation of insulin, insulin-like growth factor-1 (IGF-1), and testosterone serum levels. This downregulation of IGF-1 is associated with an increased level of insulin-like growth factor-binding protein -1 (IGFBP-1) in plasma and ovary. ${ }^{10-12}$

Effect on insulin resistance: Oral administration of the cinnamon extract (one capsule containing $333 \mathrm{mg}$, three times per day for 8 weeks) would improve insulin sensitivity in PCOS women. The insulin resistance reduction mechanism mediated through an increase in glucose utilization and potentiating phosphatidylinositol 3-kinase (PI-3 kinase) insulin signalling pathway at the post-receptor level. It leads to the translocation of glucose transporter type-4 (GLUT-4) receptor culminate and improved glucose utilization by aiding intercellular glucose transport and increasing glycogen synthesis. ${ }^{13-14}$

Effect on Menstrual irregularity: A clinical study suggests that cinnamon supplementation $(1500 \mathrm{mg} / \mathrm{day}$ for 6 months $)$ may be a useful adjunct for menstrual dysfunction in women with PCOS. The suspected mechanism is it regulates menstrual irregularity by improving insulin sensitivity. ${ }^{15}$ Effect on obesity: Oral supplementation of cinnamon $(1500 \mathrm{mg} /$ day for 8 weeks) significantly decreased serum levels of total cholesterol (TC) and low-density lipoprotein cholesterol (LDL-C) and increased high-density lipoprotein cholesterol (HDL-C) levels in women with PCOS ${ }^{16}$. The hypolipidemic effect of cinnamon might be due to its polyphenol and cinnamaldehyde content, which inhibits intestinal cholesterol absorption and increases lipolysis in adipose tissues respectively. ${ }^{17,18}$ Anti-hyperlipidemic mechanism of cinnamon mediated through the up-regulation of peroxisome proliferatoractivated receptor alpha (PPAR $\alpha$ ) expression increased cellular uptake of fatty acid and the expression of lipoprotein lipase gene. ${ }^{19}$

\section{B. Gymnema sylvestre}

Gymnema sylvestre is the most widely used ayurvedic medicine for diabetes mellitus and the lowering of serum cholesterol. ${ }^{20}$ It also effective in reducing the elevated androgen and regulate the menstrual irregularity in PCOS. Antiandrogenic 
mechanism: The ethanolic leaf extract of Gymnema sylvestre decreases the elevated androgen level in estradiol valerate induced PCOS rats. Till there is no possible anti-androgenic mechanisms were explored. ${ }^{21}$ Effect on insulin resistance: The leaf extract of Gymnema sylvestre $(400 \mathrm{mg} / \mathrm{kg})$ was reported to reduce hyperglycemia in both insulin-dependent and non-insulin-dependent diabetic patients. ${ }^{22}$ Gymnema sylvestre posse multiple antihyperglycemic mechanisms like increases in insulin secretion and glucose utilization through the insulin-dependent pathway by increased the activity of phosphorylase and decrease in gluconeogenic enzymes and sorbitol dehydrogenase. It also promotes the regeneration of islet cells. Gymnemic acid in Gymnema sylvestre prevents excess glucose absorption in the intestine by binds with glucose receptor. ${ }^{23,24}$

Effect on Menstrual irregularity: A preclinical study demonstrated that ethanolic leaves extract of Gymnema sylvestre $400 \mathrm{mg} / \mathrm{kg} /$ day regularizes the menstrual irregularity in estradiol valerate induced PCOS rats. But the study fails to explain the mechanistic approach. ${ }^{25}$

Effect on obesity: The different solvents leave extract of $G$. Sylvestre reported to possess significant hypolipidemic activities in experimentally induced obesity models. Hexane extract at $250 \mathrm{mg} / \mathrm{kg} /$ day for 28 days ${ }^{26}$, hydroalcoholic extract at $200 \mathrm{mg} / \mathrm{kg} /$ day for 7 days $^{27}$ and methanolic extract $1 \mathrm{gm} / \mathrm{kg} /$ day for 4 weeks significantly decreased the body weight gain and lowered serum total cholesterol, triglycerides (TG), very low-density lipoprotein cholesterol (VLDL), LDL, leptin and increases HDL levels. ${ }^{28}$

\section{Mentha spicata}

Mentha spicata indicated for PCOS women. Because of M. spicata effective in both the reproductive and metabolic complications of PCOS.

Antiandrogenic effect: Mentha spicata essential oil (spearmint oil) $300 \mathrm{mg} / \mathrm{kg}$ treatment daily for 20 days effectively reduced the body weight, serum testosterone level, number of atretic follicles, ovarian cyst and also increased the Graafian follicle in letrozole induced PCOS rats. ${ }^{29}$ Clinical studies also demonstrated that spearmint tea (a cup of M. Spicata $5 \mathrm{gm} / 250 \mathrm{ml}$ ) taking twice a day for 30 days decreased the free and total testosterone and increase LH and FSH. It might be concluded that $M$. spicata acts as an effective antiandrogenic agent in female patients with PCOS by decreasing free and total androgens and reduces the number of ovarian cysts. ${ }^{30,31}$

Hypoglycemic \& Hypolipidemic effect: M. spicata aqueous leaf extract (300 mg/kg for 21 days) has efficient hypoglycemic, hypolipidemic, and lipid peroxidation activities in alloxan-induced diabetic rats. ${ }^{32}$ Similarly, 14-day treatment of aqueous ethanolic fresh leaf extracts of M. spicata $400 \mathrm{mg} /$ $\mathrm{kg}$ showed an efficient anti-diabetic and moderate hypolipidemic effect in alloxan-induced diabetic rats. Those study results suggested that the anti-diabetic effect of M. spicata is mainly due to its secondary metabolites. Flavonoids, phenol, glucoside terpenoids, and steroids in M. spicata reduce the serum glucose level by stimulating the beta cells for insulin production and utilization. Carbohydrate increases glucose tolerance and release, alkaloids reduces intestinal glucose transport by inhibiting the alpha- glycosidase. ${ }^{33}$ Hence $M$. spicata acts as anti-diabetic medication by stimulating insulin production, and increase the release and utilization, also acts by reduces the intestinal glucose absorption.

\section{Pergularia daemia}

The fresh leaf extract of the Pergularia daemia is an effective medicine in normalizing the hormonal levels of the PCOS induced rats. It acts by normalizing the elevated Testosterone and Luteinizing hormone level and decreases Progesterone and Follicle-stimulating hormone (FSH) in induced PCOS. ${ }^{34}$ P. daemia has the potential to normalize menstrual irregularities and regularize the estrous cycle. Subsequently, the restoration of the estrous cycle reduces the development of follicular cyst. ${ }^{35}$ Besides, $P$. daemia also possess effective hypoglycemic and hypolipidemic properties in PCOS induced conditions. ${ }^{36,37}$ The mechanisms of action of $P$. daemia are not clear at this time; more work is required on a molecular level to delineate the process on PCOS.

\section{E. Saraka indica}

Saraka indicia dried barks and flowers are one of the most widely using Unani and Ayurvedic medications for several female disorders principally in gynaecological disorders and menorrhagia. S.indica bark has an excellent uterine and endometrial tissue stimulant effect. It is also useful in treating female disorders like painful periods, internal bleeding, haemorrhoids, menometrorrhagia, amenorrhea, menorrhagia particularly due to uterine fibroids, leucorrhoea and pimples. $^{38,39}$

$S$. indica methanolic extract $(200 \mathrm{mg} / \mathrm{kg})$ in female rats reported to possessing anti-estrogenic properties because of its phytoestrogens constituents. Hence it is effective in PCOS hormonal and reproductive complications by block the overexpression of estrogen in PCOS women. ${ }^{40}$ Phenolic glycoside $\mathrm{P} 2$ isolate from $S$. indica also reported producing oxytocic activity in both animal and human myometrial tubes. ${ }^{41} S$. indica leaves, flowers, and bark extract reported to possess hypoglycemic and hypolipidemic activity in induced diabetic conditions. Lack of molecular level findings to explore its exact mechanisms. ${ }^{42-44}$

\section{F. Saw palmetto (Serenoa repens)}

Saw palmetto indicated for PCOS, hormone imbalances (estrogen/testosterone), and benign prostatic hyperplasia. It also used to improve the genitourinary health in both sexes; this means it promotes the sexual vigour and chronic nonbacterial 
prostatitis and pelvic pain syndrome. ${ }^{45,46}$ The saw palmetto berries containing fatty acids liposterols indicated to produce significant anti-androgenic action in PCOS condition. It produces anti-androgenic action by inhibiting the 5 - $\alpha$ reductase enzyme responsible for the conversion of testosterone into its active form dihydrotestosterone (DHT) in the adrenal gland. It also reduces the $40 \%$ tissue uptake of androgens including DHT and testosterone. ${ }^{47,48}$ These mechanisms illustrated that Saw palmetto may aid in PCOS hyperandrogenism by reducing the 5- $\alpha$ reductase activity inhibits DHT production and increases DHT breakdown.

Animal studies showed that Saw palmetto regularizes the elevated prolactin-induced suppression of follicle maturation, ovulation, and formation of cysts in the PCOS ovary. Saw palmetto suppresses the elevated prolactin-induced ovarian changes by inhibiting the ovarian prolactin receptor by reducing the $\mathrm{K}^{+}$channels and protein kinase $\mathrm{C}$ basal activity involved in the prolactin transduction signals.$^{46}$ Additionally, the anti-inflammatory properties of Saw palmetto extract can also be helpful to combat bloating, pelvic pain, and lowgrade systemic inflammation in women with PCOS. ${ }^{49}$

\section{G. Tribulus terrestis}

The aerial parts and fruits of Tribulus terrestris indicated in PCOS to promote regular ovulation and reduce the ovarian cyst. ${ }^{50}$ The hydroalcoholic extract of T. terrestris $10 \mathrm{mg}$ treatment normalizes the menstrual irregularity, hormonal alterations, and efficiently removes the ovarian cysts and resumes the ovarian normal activity in the estradiol valerate induced PCOS rats. It might be due to its luteinizing effect related to it gonadotropin like activity or luteinization of follicular cysts. ${ }^{51,52}$ The proposed mechanism of T. terrestris on normalizing the hormonal level and induction of ovulation in PCOS is mainly due to its antiestrogenic action. The phytoestrogens (diosgenin, gitogenin, chlorogenin, ruscogenin, and essential oil) present in T. terrestris binds with estrogen receptor $E R \alpha$ and $E R \beta$, and act as a pure estrogen antagonist by stimulating the Gonadotropin-releasing hormone secretion. ${ }^{53}$ A randomized control study reported that $1000 \mathrm{mg} /$ day treatment of hydroalcoholic $T$. terrestris extract showed promising hypoglycemic effect and significantly reduced the total cholesterol and low-density lipoprotein in women with diabetes mellitus type 2 . These results further add up its therapeutic efficacy in PCOS. ${ }^{54}$

\section{H. Withania somnifera}

Stress is one of the major factors that affect female reproductive health by modulating ovarian physiology and reproductive hormones. This may lead to menstrual irregularity, amenorrhea, and anovulation. ${ }^{55,56}$ Many of preclinical and clinical studies proved the potent anti-stress property of Withania somnifera. It also poses a positive influence on the endocrine system. ${ }^{57}$ Withania somnifera root indicated to sup- port all endocrine functions in PCOS women. The proposed mechanism links the antioxidant features and its positive effect on hormonal imbalances of testosterone, LH, and FSH. However, the gamma-aminobutyric acid (GABA) mimetic feature of Withania somnifera extract plays a major role in the inducing gonadotropin-releasing hormone secretion and improving hormonal balance.$^{58} \mathrm{~W}$. somnifera root hydroalcoholic extract treatment increases the number of days in the estrus phase and decreases the duration of the diestrus phase. Also, it increases the FSH and decreases LH, testosterone, and estradiol in letrozole induced PCOS rats. ${ }^{53}$ Supporting finding such as hypoglycemic potency by increased insulin secretion and improved insulin sensitivity in muscles and hypolipidemic effect mediated through an increased bile acid synthesis for the elimination of body cholesterol shows the efficiency of $W$. somnifera in PCOS. ${ }^{59,60}$

\section{CONCLUSION}

Based on the available previous preclinical and clinical reported data we have selected eight plants with multiple promising effects on PCOS complications. All the selected plants were not completely screened for all PCOS complications. Still the available preliminary data revealed the therapeutic potential of the selected herbs in PCOS. The selected list of herbs is merely outnumbered in the unexplored domain of medicinal herbs having pharmacological potential. There is a need for therapeutic standardization to improve its acceptability and applications on PCOS. Further rational investigations are needed to explore deeper and extensive mechanisms of selected herbs on both reproductive and metabolic PCOS complications. This extensive review will support the researchers and phytotherapist to explore more standard herbal polyherbal formulations/remedies for PCOS.

\section{ACKNOWLEDGEMENT}

The authors are acknowledged to the Chancellor, Vinayaka Mission's Research Foundation (Deemed to be University), Salem for providing necessary support for writing this article.

\section{Conflict of interest- Nil}

\section{Source of funding - Nil}

\section{REFERENCES}

1. Norman RJ, Dewailly D, Legro RS, Hickey TE. Polycystic ovary syndrome. Lancet 2007; 370:685-697.

2. Salley KE, Wickham EP, Cheang KI, Essah PA, Karjane NW, Nestler JE. Glucose intolerance in polycystic ovary syndrome-a position statement of the Androgen Excess Society. J Clin Endocrinol Metab 2007; 92:4546-4556. 
3. Ni RM, Mo Y, Chen X, Zhong J, Liu W, Yang D. Low prevalence of the metabolic syndrome but the high occurrence of various metabolic disorders in Chinese women with polycystic ovary syndrome. Eur J End 2009; 161:411-418.

4. Wild RA, Carmina E, Diamanti-Kandarakis E, Dokras A, Escobar-Morreale HF, Futterweit W, et al. Assessment of cardiovascular risk and prevention of cardiovascular disease in women with the polycystic ovary syndrome: a consensus statement by the Androgen Excess and Polycystic Ovary Syndrome (AEPCOS) Society. J Clin Endocrinol Metab 2010; 95:2038-2049.

5. Chaudhari AP, Mazumdar K, Mehta PD. Anxiety, Depression, and Quality of Life in Women with Polycystic Ovarian Syndrome. Indian J Psychol Med 2018; 40(3):239-246.

6. Hywood NDA, Bone K. Phytotherapy for the polycystic ovarian syndrome. Medi Herb A Physioth Pers 2004; 1:46.

7. Arentz S, Abbott JA, Smith CA, Bensoussan A. Herbal medicine for the management of polycystic ovary syndrome (PCOS) and associated oligo/amenorrhoea and hyperandrogenism; a review of the laboratory evidence for effects with corroborative clinical findings. BMC Complementary Alt Med 2014; 14:511.

8. Lunny CA, Fraser SN. The Use of Complementary and Alternative Medicines among a Sample of Canadian Menopausal Aged Women. J Midwifery Womens Health 2010; 55(4):335-343.

9. Bishop JL, Northstone K, Green JR, Thompson EA. The use of complementary and alternative medicine in pregnancy: data from the Avon Longitudinal Study of Parents and Children (ALSPAC). Complement Ther Med 2011; 19(6):303-310.

10. Dou L, Zheng Y, Li L, Gui X, Chen Y, Yu M, Guo Y. The effect of cinnamon on polycystic ovary syndrome in a mouse model. Repro Bio Endoc 2018; 16:1-10.

11. Bergh C, Carlsson B, Olsson JH, Selleskog U, Hillensjo T. Regulation of androgen production in cultured human thecal cells by insulin-like growth factor I and insulin. Fertil Steril 1993; 59:323-31.

12. Nagamani M, Stuart CA. Specific binding sites for insulin-like growth factor I in the ovarian stroma of women with polycystic ovarian disease and stromal hyperthecosis. Am J Obstet Gynecol 1990; 163:1992-1997.

13. Wang JG, Anderson RA, Graham GM, Chu MC, Sauer MV, Guarnaccia MM, Lobo RA. The effect of cinnamon extract on insulin resistance parameters in polycystic ovary syndrome: a pilot study. Fertil Steril 2007; 88(1):240-243.

14. Qin B, Nagasaki M, Ren M, Bajotto G, Oshida Y, Sato Y. Cinnamon extract (traditional herb) potentiates in vivo insulin-regulated glucose utilization via enhancing insulin signalling in rats. Diab Res Clin Pract 2003; 62:139-148.

15. Kort DH, Lobo RA. Preliminary Evidence that Cinnamon Improves Menstrual Cyclicity in Women with Polycystic Ovarian Syndrome: a Randomized Controlled Trial. Am J Obstet Gynecol 2014; 211(5):487e1-487e6.

16. Borzoei A, Rafraf M, Niromanesh S, Farzadi L, Narimani F, Doostan F. Effects of cinnamon supplementation on antioxidant status and serum lipids in women with polycystic ovary syndrome. J Trad Compl Med 2018; 8(1):128-133.

17. Shalaby MA, Saifan HY. Some pharmacological effects of cinnamon and ginger herbs in obese diabetic rats. J Int Ethnopharmacol 2014; 3:144-149.

18. Khare P, Jagtap S, Jain Y, Bishnoi M. Cinnamaldehyde supplementation prevents fasting-induced hyperphagia, lipid accumulation and inflammation in high-fat diet-fed mice. Article Bio Factors 2016; 42:77.

19. Sheng X, Zhang Y, Gong Z, Huang C, Zang YQ. Improved insulin resistance and lipid metabolism by cinnamon extract through activation of peroxisome proliferator-activated receptors. PPAR Res 2008; 58:1348.
20. Packialakshmi B, Sowndriya SR. Anti-cancer effect of Gymnema sylvestre Leaf Extract against MG63, Human Osteosarcoma cell line - An in vitro analysis. Int J Curr Res Rev 2019; 11(11):18-24.

21. Sreesaila NP, Nirmala P. Effect of Ethanolic extracts of Amorphophallus paeoniifolius and Gymnema sylvestre on female wistar rats with estradiol induced polycystic ovarian syndrome. World J Pharma Res 2013; 7(13):1053-1060.

22. Shanmugasundaram ERB, Rajeswar G, Baskaran K, Kumar BRR, Shanmugasundaram KR, Ahmath BK. Use of Gymnema sylvestre leaf extract in the control of blood glucose in insulindependent Diabetes Mellitus. J Ethnopharmacol 1990; 30:281294.

23. Baskaran K, Ahamath BK, Shanmugasundaram KR, Shanmugasundaram ERB. Antidiabetic effect of a leaf extracts from Gymnema sylvestre in non-insulin-dependent Diabetes mellitus patients. Journal of Ethnopharmacology 1990; 30:295-305.

24. Laha S, Paul S. Gymnema sylvestre (Gurmar): A Potent Herb with Anti-Diabetic and Antioxidant Potential. Pharmacognosy J 2019; 11(2):201-206.

25. Sudhakar P, Suganeswari M, Poorana Pushkalai S, Haripriya S. Regulation of Estrous cycle using Combination of Gymnema sylvestre and Pergularia daemia in estradiol valerate induced PCOS rats. Asian J Res Pharma Sci 2018; 8(1):4-8.

26. Kaushik M, Kaushik A, Arya R, Singh G, Malik P. Antiobesity property of hexane extract from the leaves of Gymnema sylvestre in high fed cafeteria diet induced obesity rats. Int Res J Pharmacy $2011 ; 2: 112-116$.

27. Rachh PR, Rachh MR, Ghadiya NR, Modi DC, Modi KP, Patel NM, et al. Anti-hyperlipidemic activity of Gymenma sylvestreR. $\mathrm{Br}$. leaf extract on rats fed with high cholesterol diet. Int J Pharmacol 2010; 6(2):138-141.

28. Kim HJ, Hong SH, Chang SH, Kim S, Lee AY, Jang Y, et al. Effects of feeding a diet containing Gymnemasylvestre extract: Attenuating progression of obesity in $\mathrm{C} 57 \mathrm{BL} / 6 \mathrm{~J}$ mice. Asian Pac J Trop Med 2016; 9(5):437-444.

29. Ataabadi MS, Alaee S, Bagheri MJ, Bahmanpoor S. Role of Essential Oil of Mentha spicata (Spearmint) in Addressing Reverse Hormonal and Folliculogenesis Disturbances in a Polycystic Ovarian Syndrome in a Rat Model. Adv Pharm Bull 2017; 7(4):651-654.

30. Akdogan M, Tamer MN, Cure E, Cure MC, Koroglu BK, Delibas N. Effect of spearmint (Mentha spicata Labiatae) teas on androgen levels in women with hirsutism. Phytother Res 2007; 21:444-447.

31. Grant P. Spearmint herbal tea has significant anti-androgen effects in polycystic ovarian syndrome. A randomized controlled trial. Phytother Res 2010; 24:186-188.

32. Bayani M, Ahmadi-hamedani M, Javan AJ. Study of Hypoglycemic, Hypocholesterolemic and Antioxidant Activities of Iranian Mentha Spicata Leaves Aqueous Extract in Diabetic Rats. Iranian J Pharma Res 2017; 16:75-82.

33. Mushtaq A, Iqbal N, Jamil M, Khawaja NR, Gohar UF, Mehmood MA. Anti-diabetic and Anti-hyperlipidemic action of aqueous ethanolic extracts of Mentha spicata (Leaves), Plumeria alba (Leaves) and Nymphaeaalba (Flowers and Rhizomes). IJBPAS 2017; 6(1):108-124.

34. Bhuvaneshwari S, Poornima R, Averal HI. Comparative study of Pergulariadaemia and Citrulluscolocynthis in polycystic ovarian syndrome induced albino wistar rats. Int J Multidisc Res Dev 2015; 2(9):207-212.

35. Nivetha S, Poornima R, Horne Iona Averal. Regularization of Estrous Cycle Using Pergularia daemia and Metformin in the PCOS Induced Rats. Int J Pharma Res Scholars 2016; 5(3):99103. 
36. Doss A, Anand SP. Antihyperglycemic activity of methanol and aqueous extracts of Pergularia daemia Linn. African J Biotech 2014; 13(1):170-174.

37. Bhuvaneshwari S, Poornima R, Averal HI. Management of obesity in polycystic ovary syndrome induced albino rats with Pergularia daemia. Int J Appl Res 2015; 1(9):779-783.

38. Nyeem MAB, Haque MS, ObaydulHaq MD, Nuruzzaman M, Uddin H, Rabiul Islam BM. Ashoka (Saraca indica) as women friendly plant: A review. Nat J Adv Res 2017; 3(2):03-07.

39. Singh S, Krishna THA, Kamalraj SS, Kuriakose GC, Valayil JM, Jayabaskaran C. Phytomedicinal importance of Saraca asoca (Ashoka): an exciting past, an emerging present and a promising future. Curr Sci 2015; 109(10):1790-1801.

40. Shahid AP, Salini S, Sasidharan N, Padikkala J, Raghavamenon AC, Babu TD. Effect of Saraca asoca (Asoka) on estradiol induced keratinizing metaplasia in rat uterus. J Basic Clin Physiol Pharmacol2015; 26(5):509-516.

41. Satyavati GV, Prasad DN, Sen SP, Das PK. Oxytocic activity of a pure phenolic glycoside (P2) from Saracaindica Linn (Ashoka): a short communication. Indian J Med Res 1970; 58:660-663.

42. Kumar S, Narwal S, Kumar D, Singh G, Narwal S, Arya R. Evaluation of antihyperglycemic and antioxidant activities of Saracaasoca (Roxb.) De Wild leaves in streptozotocin induced diabetic mice. Asian Pac J Trop Dis 2012; 2(3):170-176.

43. Preethi F, Fernandes J, Pricilla K. Hypoglycemic activity of $\mathrm{Sa}$ raca indica Linn barks. J Pharmacy Res 2010; 3(3):491-493.

44. Mishra SB, Vijayakumar M. Anti-Hyperglycemic and Antioxidant Effect of Saraca asoca (Roxb. De Wilde) Flowers in Streptozotocin Nicotinamide Induced Diabetic Rats: A Therapeutic Study. J Bioanal Biomed 2014; 12:1-5.

45. Liepa GU, Sengupta A, Karsies D. Polycystic ovary syndrome (PCOS) and other androgen excess-related conditions: can changes in dietary intake make a difference. Nutr Clin Pract 2008; 23(1):63-71.

46. Stansbury J. Saw Palmetto May Reduce Elevated Androgens and Prolactin in Women with PCOS. Restorative Med 2016.

47. Meletis CD, Nieske Zabriskie N. Natural Approaches for Treating Polycystic Ovary Syndrome. Altern Complement Therap 2006; 15:157-164.

48. Silverio DF, Monti S, Sciarra A, Varasano PA, Martini C, Lanzara S, et al. Effects of long-term treatment with Serenoa repens (Permixon) on the concentrations and regional distribution of androgens and epidermal growth factor in benign prostatic hyperplasia. Prostate 1998; 37:77-83.

49. Behl MS, Saw Palmetto for PCOS: Reduce Excess Male Hormones Naturally. Available from: http://www.https://www.sepalika.com/pcos/saw-palmetto-for-pcos.

50. Barton D, Doula CH. How to use fertility herbs to enhance your fertility naturally. Available from http://E;/pcod/fertility Herbs Infertility Treatment Pregnancy Herbs.htm. Accessed June, 2020.

51. Dehghan A, Esfandiari A, Momeni S. Bigdeli, Alternative treatment of ovarian cysts with Tribulus terrestris extract: A rat model. Reprod Domest Ani 2012; 47(1):12-15.

52. Esfandiari A, Dehghan A, Sharifi S, Najafi B, Vesali E. Effect of Tribulus terrestris extract on ovarian activity in immature Wistar rat: a histological evaluation. J Anim Vet Adv 2011; 10(7):883886.

53. Saiyed A, Jahan N, Ahmed Makbul SA, Ansari M, Bano H, Habib SH. Effect of combination of Withaniasomnifera Dunal and Tribulus terrestris Linn on letrozole induced polycystic ovarian syndrome in rats. Integr Med Res 2016; 5:293-300.

54. Samani NB, Jokar A, Soveid M, Heydari M, Mosavat SH. Efficacy of the Hydroalcoholic Extract of Tribulus terrestris on the Serum Glucose and Lipid Profile of Women with Diabetes Mel- litus: A Double-Blind Randomized Placebo-Controlled Clinical Trial. J Evid Based Complement Altern Med 2016; 21(4):91-97.

55. Ebbesen SMS, Zachariae R, Mehlsen MY, Thomsen D, Hojgaard A, Ottosen L, et al. Stressful life events are associated with a poor in-vitro fertilization (IVF) outcome: a prospective study. Hum Reprod 2009; 24:2173-2182.

56. Allsworth JE, Clarke J, Peipert JF, Hebert R, Cooper A, Boardman LA. The influence of stress on the menstrual cycle among newly incarcerated women. Womens Health Issues 2007; 17:202-209.

57. Ashok GA, Shende MB, Chothe DS. Antistress activity of ashwagandha (Withania somnifera Dunal) - a review. Int Ayu Med J 2014; 2(3):386-393.

58. Azgomi RND, Zomorrodi A, Nazemyieh H, BagherFazljou SM, Bazargani HS, Nejatbakhsh F, et al. Effects of Withania somnifera on Reproductive System: A Systematic Review of the Available Evidence. Bio Med Research International 2018; 4076430:1-17.

59. Gorelick J, Rosenberg R, Smotrich A, Hanus L, Bernstein N. Hypoglycemic activity of withanolides and elicitated Withania somnifera. Phytochemistry 2015; 116:283-289.

60. Visavadiya NP, Narasimhacharya AVRL. Hypocholesteremic and antioxidant effects of Withania somnifera (Dunal) in hypercholesteremic rats. Phytomedicine 2007; 14:136-142.

61. Rao PV, Gan SH. Cinnamon: A Multifaceted Medicinal Plant. Evidence-Based Complement Altern Med 2014; 2014: 1-12.

62. Ranasinghe P, Pigera S, Premakumara GAS, Galappaththy P, Constantine GR, Katulanda P. Medicinal properties of 'true' cinnamon (Cinnamomum zeylanicum): a systematic review. BMC Complement Altern Med 2013; 13:275.

63. Anand V, Varalakshmi, Prasana, Sampath Kumar, Pushpa, AgaathHedina. Cinnamomum zeylanicum Linn. The spice with multi potential. Syste Rev Pharmacy 2016; 7(1):24-29.

64. Tiwari P, Mishra BN, Sangwan NS. Phytochemical and Pharmacological Properties of Gymnema sylvestre: An Important Medicinal Plant. BioMed Res Int 2014; 2014:1-18.

65. Tetik F, Civelek S, Cakilcioglu U. Traditional uses of some medicinal plants in Malatya (Turkey). J Ethnopharmacol 2013; 146:331-346.

66. Kee LA, Shori AB, Baba AS. Bioactivity and health effects of Mentha spicata. Integr Food Nutr Metab 2017; 5(1):1-2.

67. Karthishwaran K. Mirunalini S. Therapeutic potential of Pergularia daemia (Forsk.): The Ayurvedic wonder. Int J Pharmacol 2010; 6(6):836-843.

68. Bhaskar VH, Balakrishnan N. Veliparuthi (Pergularia daemia (Forsk.) Chiov.) - As a phytomedicine: A review. Int J Pharm Tech Res 2009; 1(4):1305-1313.

69. Pachiappan S, Matheswaran S, Saravanan PP, Muthusamy G. Medicinal plants for polycystic ovary syndrome: A review of phytomedicine research. Int J Herb Med 2017; 5(2):78-80.

70. Sharma PC, Yelne MB, Dennis TJ. Database on medicinal plants used in Ayurveda, Central Council for Research in Ayurveda and Siddha, Department of ISM\&H, Ministry of Health and Family Welfare (Govt. of India), New Delhi. 2005; 3:76-8.

71. Mishra A, Kumar A, Rajbhar N, Kumar A. Phytochemical and Pharmacological Importance of Saraca indica. Int J Pharma Chem Sci 2013; 2(2):1009-1013.

72. Suzuki M, Ito Y, Fujino T, Abe M, Umegaki K, Onoue S, et al. Pharmacological effects of saw palmetto extract in the lower urinary tract. Acta Pharmacol Sin 2009; 30(3): 271-281.

73. Fagelman E, Lowe FC. Saw Palmetto Berry as a Treatment for BPH. Rev Urol 2001; 3(3):134-138.

74. Kalwat JI. The Use of Serenoa repens (Saw Palmetto) in Hair Care Products. Biomed J Sci Tech Res 2019; 13(1):9725-9728. 
75. Zhu W, Du Y, Meng H, Dong Y, Li L. A review of traditional pharmacological uses, phytochemistry, and pharmacological activities of Tribulus terrestris. Chem Cent J 2017; 11:60.

76. Akram M, Asif HM, Akhtar N, Shah PA, Uzair M, Shaheen G, et al. Tribulu sterrestris Linn.: A review article. J Med Plants Res 2011; 5(16):3601-3605.

77. Amin A, Lotfy M, Shafiullah M, Adeghate E. The Protective Effect of Tribulus terrestris in Diabetes. Ann NY Acad Sci 2006; 1084:391-401.
78. Narinderpal K, Junaid N, Raman B. A Review on Pharmacological Profile of Withania somnifera (Ashwagandha). Res Rev J Bot Sci 2013; 2(4):6-14.

79. Singh N, Bhalla M, De Jager P, Gilca M. An overview on Ashwagandha: A Rasayana (Rejuvenator) of Ayurveda. Afr J Tradit Complement Altern Med 2011; 8:208-213.

Table 1: Phytopharmacological data of the selected plants

\begin{tabular}{|c|c|c|c|c|}
\hline $\begin{array}{l}\text { Medicinal plants } \\
\text { \& Scientific name }\end{array}$ & Family & $\begin{array}{l}\text { Commonly } \\
\text { used Plant } \\
\text { Parts }\end{array}$ & Traditional climes & Reported activities References \\
\hline
\end{tabular}

Cinnamomum Lauraceae Steam bark, Increases the blood circulation zeylanicum L. (Cin- Leaves in the uterus and advances tissue namon)

Gymnema sylvestre Asclepiadaceae Leaves, Flowers and bark
Mentha spicata L. Labiatae

(spearmint)
Fresh or dried plant, Leaves, spearmint oil regeneration, As tooth powder to treat toothaches, dental problems, oral microbiota, and bad breath. It can also improve the health of the colon, thereby reducing the risk of colon cancer.

Diabetes, Malaria, antihelminthic, antipyretic, astringent, cardiotonic, digestive, diuretic, cough, dyspepsia, hemorrhoids, hepatosplenomegaly, laxative, stimulant, stomachic, uterine tonic, intermittent fever, jaundice, leucoderma. Snakebites, urinary disorders, and respiratory diseases.

Colds, fever and flu, respiratory tract problems, gastralgia, hemorrhoids, and stomachache, also used as carminative to treat digestive disorders
Antidiabetic, Cardio- $\quad 61,62,63$ protective, Antioxidant, Neuroprotective, Anti Alzheimer's, Anti-inflammatory, Hepatoprotective, Antimicrobial, and Anticancer activity.

Pergularia daemia Apocynaceae (Forsk.)
Arial parts, Stem bark, Leaves, Roots, fruit, Latex
Gastric ulcer, uterine and menstrual Uterine stimulant, complaints (Amenorrhea, dysmen- analgesic, antipyretic, orrhea), hemorrhoids, abortifacient, anti-inflammatory, Uterine tonic infantile diarrhoea, bronchitis, whooping cough, cold, heals cuts and wounds, antipyretic and appetizer.

CNS depressant, hepatoprotective, Anti-fertility, antioxidant, anti-cancer,
Anti-arthritic, Antihyperlipidemic, Antidiabetic, Immunostimulatory, Hepatoprotective, Wound Healing, Antiarthritic, Anti-inflammatory Anticancer, and Cytotoxic.

Antispasmodics, anti- 65, 66, 29, platelets, antioxidant, 31, 32 anti-microbial,

Hypoglycemic, Hypocholesterolemic, Anti-androgen, Reverse hormonal, and folliculogenesis disturbances in PCOS.

$64,24,22$ Antidiabetic, anti-bacterial, antifungal and anti-malarial activity. 
Table 1: (Continued)

\begin{tabular}{|c|c|c|c|c|c|}
\hline $\begin{array}{l}\text { Medicinal plants } \\
\text { \& Scientific name }\end{array}$ & Family & $\begin{array}{l}\text { Commonly } \\
\text { used Plant } \\
\text { Parts }\end{array}$ & Traditional climes & Reported activities & References \\
\hline Saraca indica L. & Leguminosae & $\begin{array}{l}\text { Leaves, Flowers, } \\
\text { Barks, } \\
\text { Seeds }\end{array}$ & $\begin{array}{l}\text { Useful in several feminine disorders } \\
\text { like internal bleeding, hemorrhoids, } \\
\text { ulcers, uterine affections, menor- } \\
\text { rhagia especially due to uterine } \\
\text { fibroids, menometrorrhagia, leucor- } \\
\text { rhoea, and pimples. }\end{array}$ & $\begin{array}{l}\text { Anti-inflammatory, } \\
\text { Analgesic, Antipy- } \\
\text { retic, Antioxidant, } \\
\text { Immunomodulatory, } \\
\text { Antimenorrhagic, } \\
\text { Uterine tonic, Anti- } \\
\text { oxytocic, Antidiabetic, } \\
\text { CNS depressant, } \\
\text { Cardioprotective and } \\
\text { Anticancer activity. }\end{array}$ & $38,70,71$ \\
\hline $\begin{array}{l}\text { Saw palmetto } \\
\text { (Serenoarepens) }\end{array}$ & Arecaceae & Berries, oil & $\begin{array}{l}\text { To cure genitourinary } \\
\text { disturbances, relieve mucous mem- } \\
\text { brane irritations, increase } \\
\text { testicular function, the breast size. }\end{array}$ & $\begin{array}{l}\text { Antiandrogen, } \\
\text { anti-proliferative and } \\
\text { anti-inflammatory, } \\
\text { Effective in Androge- } \\
\text { netic alopecia, Pros- } \\
\text { tate hypertrophy. }\end{array}$ & $72,73,74$ \\
\hline $\begin{array}{l}\text { Tribulu sterrestris } \\
\text { L. }\end{array}$ & Zygophyllaceae & Arial parts, Fruits & $\begin{array}{l}\text { Used in infertility, } \\
\text { impotence, erectile dysfunction, low } \\
\text { libido, tonic, aphrodisiac, diuretic, } \\
\text { urinary disorders, hyperuricemia, } \\
\text { expectorant, improves eyesight and } \\
\text { to relieve rheumatic pain. }\end{array}$ & $\begin{array}{l}\text { Libido enhancing } \\
\text { activity, Effective in } \\
\text { erectile dysfunction, } \\
\text { Fertility improver, } \\
\text { Hypoglycemic, Hy- } \\
\text { polipidemic, Anti } \\
\text { urolithiatic, analgesic, } \\
\text { antioxidant, anti- } \\
\text { inflammatory, } \\
\text { Anti-aging, cardio- } \\
\text { protective, neuropro- } \\
\text { tective, diuretic and } \\
\text { uricosuric. }\end{array}$ & $75,76,77$ \\
\hline $\begin{array}{l}\text { Withania somnifera } \\
\text { Dunal } \\
\text { (Ashwagandha) }\end{array}$ & Solanaceae & $\begin{array}{l}\text { Root } \\
\text { Leaves, } \\
\text { Flowers, seeds }\end{array}$ & $\begin{array}{l}\text { Treatment of tumors and tubercu- } \\
\text { lar glands, a tonic for vitality and } \\
\text { longevity, Adaptogen, aphrodisiac, } \\
\text { narcotic, diuretic, anthelmintic, } \\
\text { astringent, ulcers and painful swell- } \\
\text { ings, thermogenic and stimulant. }\end{array}$ & $\begin{array}{l}\text { Abortifacient, aphro- } \\
\text { disiac, Anti-hypergly- } \\
\text { cemic, Hypolipidemic, } \\
\text { Immunomodulatory, } \\
\text { Cardioprotective, } \\
\text { Antiparkinsonian, } \\
\text { Nootropic, Anticon- } \\
\text { vulsant, Anti-aging, } \\
\text { Antioxidant, Anti- } \\
\text { stress, anti-arthritic } \\
\text { and anti-inflamma- } \\
\text { tory }\end{array}$ & $60,78,79$ \\
\hline
\end{tabular}


Table 2: Selected medicinal plants and their mechanism of action on PCOS

Medicinal plants
Cinnamomum zeylanicum
PCOS

Antiandrogenic, Normalize the disrupts folliculogenesis and menstrual cyclicity Improves insulin sensitivity Antihyperlipidemic

Gymnema sylvestre

Mentha spicata Antiandrogenic and regularize the
menstrual irregularity

Improves insulin sensitivity

Hypolipidemic

Anti androgenic, Reduce atretic follicles, ovarian cyst and also increased the Graafian follicle in PCOS

Hypoglycemia, Hypolipidemia and lipid peroxidation activities
Mechanism of action

References

Cinnamomum acts by down-regulate serum levels of testosterone, insulin and decreases IGF-1 level while increase

11,12 13,14 IGFBP-1level in plasma as well as in the ovary of patients with PCOS.

Reduced insulin resistance mediated through an increase in glucose utilization, by potentiating insulin signaling at the post-receptor level, increasing PI-3 kinase activity. This leads to the translocation of GLUT-4 receptors and the attenuation of the tonic inhibition on glycogen synthase, culminating in improved glucose utilization by facilitating intracellular glucose transport and increasing glycogen synthesis.

Cinnamon regulated lipid metabolism via the up-regulation of Peroxisome proliferator-activated receptor alpha (PPAR $\alpha$ ) expression increased the cellular uptake of fatty acids liberated from fat tissues. PPAR $\alpha$ ligands also increased the expression of the lipoprotein lipase gene, resulting in the anti-hyperlipidemia effect.

Decrease the elevated androgen level in induced PCOS. But the possible mechanism was not explored.

It increases glucose utilization shown by increase the activities of enzymes responsible for the utilization of glucose by insulin-dependent pathways, an increase in phosphorylase activity, a decrease in gluconeogenic enzymes and sorbitol dehydrogenase. It also increases insulin secretion and promotes the regeneration of islets cells.

It possesses significantly reduces the total cholesterol, TG, LDL, VLDL, and leptin in induced condition.

By decrease the free and total testosterone and an increase in luteinizing hormone and follicle-stimulating hormone.

The present secondary metabolites flavonoids reduce the serum glucose level and stimulate beta cells for insulin production. Phenol and flavonoids increase the utilization of insulin and reduce glucose level, alkaloids inhibit $\alpha$-glucosidase by decreasing glucose transport through the intestinal epithelium. 
Table 2: (Continued)

$\begin{array}{ll}\text { Medicinal plants } & \begin{array}{l}\text { Reported activities in relation to } \\ \text { PCOS }\end{array} \\ \text { Pergularia daemia } & \begin{array}{l}\text { Normalizing the hormonal levels in } \\ \text { PCOS }\end{array} \\ & \begin{array}{l}\text { Normalizing menstrual irregularities } \\ \text { and regularizing the estrous cycle }\end{array} \\ & \text { Hypoglycemic and Hypolipidemic }\end{array}$

Mechanism of action

References

Decrease elevated Testosterone and LH

level and Increase the decreased Proges-

34

terone and FSH level in PCOS.

By restoration of the estrous cycle, Pergu-

laria daemia reduces the development of follicular cysts.

Possess hypoglycemic and hypolipidemic in PCOS induced condition.

Saraca indica

Saw palmetto

Tribulu sterrestis

Withania somnifera
Antiestrogenic,

Oxytocic

Hypoglycemic and Hypolipidemic

Anti androgenic

Inhibit prolactin level

Anti-inflammatory

Normalize the hormonal level, Promote regular ovulation and reduce ovarian cyst in PCOS

Anti stressor, Antioxidant, Anti androgenic, Improves follicular development

Hormone regulation in PCOS

Hypoglycemic activity

Hypocholesterolemic effect
Phytoestrogens in Saraca indica suppress the estrogen-induced endocrine and reproductive systems associated with malfunctions of reproductive organs.

Liposterols in Saw palmetto produce anti-androgenic effects by inhibits 5 $\alpha$-reductase to reduce the uptake of androgens, also by increases DHT breakdown and inhibits DHT production and binding to androgen receptor sites.

Saw Palmetto inhibits prolactin receptors on ovarian cells and reduces the basal activity of $\mathrm{K}(+)$ channels and protein kinase $C$ involved with the transduction of prolactin signals.

Reduce low-grade systemic inflammation in women with PCOS.

38,39

47,48

46

Phytoestrogens present in Tribulus terrestis binds with estrogen receptors ER $\alpha$ and ER $\beta$ and acts as a pure estrogen antagonist by stimulating Gonadotropin-releasing hormone secretion. Such this mechanism it normalizes the hormonal level and induction of ovulation in PCOS.

Increase the level of stress hormone cortisol may reduce estradiol-17 $\beta$ biosynthesis in the ovary. It results in amenorrhea, anovulation, and menstrual irregularities in females. WS regulate this condition by reducing this stress hormone.

GABA mimetic feature of WS extract is 58 thought to play the main role in inducing gonadotropin-releasing hormone secretion and improving hormonal balance.

Increased insulin secretion and improved insulin sensitivity in muscle cells.

Mediated through an increased bile acid synthesis for the elimination of body cholesterol in PCOS. 